\title{
IНВЕСТУВАННЯ В УНІВЕРСИТЕТСЬКІ КЛІНІКИ НА ОСНОВІ МЕХАНІЗМУ ДЕРЖАВНО-ПРИВАТНОГО ПАРТНЕРСТВА
}

\author{
Стоматологічний медичний центр Національного медичного університету імені О. О. Богомольця, \\ м. Київ, Україна
}

\begin{abstract}
Мета: розглянути можливість інвестування в університетські клініки на основі використання механізму державноприватного партнерства (ДПП).

Матеріали і методи. Для досягнення поставленої мети у роботі використано загальнонаукові методи аналізу, синтезу, узагальнення, інтерпретації наукових даних, а також системний і структурно-фрункціональний підходи. Інфрормаційною базою дослідження $є$ наукові праці вітчизняних і зарубіжних спеціалістів із державно-приватного партнерства та менеджменту.

Результати. Обмеження фінансових ресурсів в охороні здоров'я зумовило потребу інвестувань в університетські клініки та необхідність пошуку нових, ефективних фрорм реалізації інвестиційної діяльності.

У статті розглянуто можливість інвестування в університетські клініки на основі використання механізму державно-приватного партнерства. При переході університетської клініки на роботу на принципах державно-приватного партнерства змінюється статус клініки, вона стає юридично і господарсько самостійним закладом, у якому управління переходить до приватного інвестора, але сама клініка залишається у державній власності. Інвестування реалізується на основі договору і програм із визначенням прав та обов'язків партнерів. Запропоновано алгоритм реалізації проекту державно-приватного партнерства, який забезпечує інвестування і срормування сучасних клінічних баз університетів, розвиває бізнес-процеси, що залучають ресурси приватного інвестора і підвищують есрективність роботи університетської клініки.
\end{abstract}

Висновки. У статті визначені вектори інвестування в університетські клініки через механізми державноприватного партнерства, а також основні умови реалізації дПП в університетських клініках.

КЛЮчОВІ СЛОВА: університетська клініка; державно-приватне партнерство.

Актуальність дослідження зумовлена необхідністю залучення приватних інвестицій у сореру університетських клінік (УК) із метою вдосконалення їх діяльності. Обмеження фрінансових ресурсів в охороні здоров'я зумовило проблему інвестувань в університетські клініки та необхідність пошуку нових, ефективних фрорм реалізації інвестиційної діяльності.

Об'єктивний аналіз засвідчує наявність суттєвих проблем у фінансуванні системи охорони здоров'я України. Так, за даними експерта УІАМП Данила Богатирьова, фрінансування охорони здоров'я за останні 5 років скоротилося вдвічі і «сьогодні на охорону здоров'я витрачається 2,6 \% ВВП України» [3]. У найближчі роки його збільшення чекати не доводиться.

Сучасна світова економіка характеризується новими формами взаємодії бізнесу і держави. Однією з них є державно-приватне партнерство, націлене на збільшення масштабів залучення приватних інвестицій до державного сектору.

Зарубіжний досвід засвідчує, що використання механізмів державно-приватного партнерства у системі охорони здоров'я дозволяє оптимізувати витрати державного бюджету; забезпечити

(с) В. Д. Чопчик, 2019 конкурентоздатність закладів охорони здоров'я, систематизувати ринок приватних медичних послуг і розвивати його з урахуванням реальних потреб конкретних закладів охорони здоров'я; інвестувати додаткові ресурси у об'єкти охорони здоров'я; створювати мережу нових клінік, запроваджувати у них сучасні медичні технології; залучати висококваліфікований персонал, підвищувати якість і доступність медичних послуг для населення та рівень сервісу [5, 8-10].

Мета дослідження: розглянути можливість інвестування в університетські клініки на основі використання механізму державно-приватного партнерства (ДПП).

Матеріали і методи. Для досягнення поставленої мети у роботі використано загальнонаукові методи аналізу, синтезу, узагальнення, інтерпретації наукових даних, а також системний і структурно-функціональний підходи. Інфрормаційною базою дослідження $є$ наукові праці вітчизняних і зарубіжних спеціалістів із ДПП та менеджменту.

Результати дослідження та їх обговорення. Наслідки економічної кризи в Україні, скорочення фрінансових можливостей державного сектору, значне скорочення витрат на утримання системи охорони здоров'я вимагають пошуку більш ефективних джерел інвестування. 
У сучасних економічних умовах країни актуальним $€$ залучення механізмів ДПП і приватних інвестицій у розвиток університетських клінік, що зумовить зміну організаційно-правового статусу УК - вони стануть юридично і господарсько самостійними установами, а також забезпечить їх економічну стійкість, підвищення ефрективності навчального, наукового процесів і якості медичної допомоги $[2,6]$.

Існує багато різних визначень державно-приватного партнерства. Найбільш загальну дефініцію дає Світовий банк: «ДПП - це угоди між публічною і приватною сторонами з приводу виробництва і надання інфрраструктурних послуг, які укладаються з метою залучення додаткових інвестицій i, що ще більш важливо, як засіб підвищення ефективності бюджетного фрінансування» [4].

Аналіз досвіду зарубіжних країн засвідчує, що інституційна основа передачі державних функцій і громадського управління в охороні здоров'я приватним інвесторам виникла досить давно. Багато розвинених країн на практиці застосовують принципи ДПП, створюючи асоціації у сорері медицини [1, 7]. Зарубіжні лікарі переконані, що нова система організації надання медичних послуг перевершує альтернативні методи управління і їх професійна діяльність на принципах ДПП організована відповідно до етичних норм.

ДПП має певні соціально-економічні передумови і особливо це стосується таких «громадських сорер», як охорона здоров'я. Приватний бізнес в умовах зростаючої конкуренції також зацікавлений у розширенні своєї діяльності через надання державі інвестицій.

Об'єднання фрінансових ресурсів державного і приватного сектору дозволяє ефективніше вирішувати соціальні завдання. Від об'єднання у формі ДПП виграють і бізнес, і держава. Зрештою, це сприяє підвищенню якості життя населення і посиленню конкурентоздатності. Основа успішності об'єднання фрінансових ресурсів у концепції ДПП полягає у тому, що і держава, і приватний сектор мають свою специфріку діяльності і свої переваги, при об'єднанні яких фрормується ця кооперація і створюється ефрект синергії. З'являється можливість більш ефективно працювати і досягати кращих результатів, насамперед у сфері охорони здоров'я та вищої медичної освіти.

На основі вищевикладеного, а також діагностики фрінансово-економічного стану УК, можна зробити висновок про доцільність розробки моделі університетської клініки на принципах державноприватного партнерства.

При побудові моделі партнерства варто виходити 3 інтересів партнерів. Тому важливо спочатку виявити і проаналізувати ці інтереси. Сторони повинні відкрито заявити про свої інтереси та послідовно відстоювати їх. В іншому разі партнерство стане нестійким.

Наступним важливим моментом $€$ аналіз ресурсів, які пропонуються для проведення спільної діяльності кожною зі сторін. Аналіз ресурсів дозволяє встановити:

- наскільки реальною $є$ можливість співробітництва сторін;

- чи буде забезпечена запланована спільна діяльність ресурсами;

- яким буде баланс вкладених у ведення спільної діяльності ресурсів.

Після врахування інтересів сторін і аналізу ресурсів партнерства необхідно спланувати спільну діяльність сторін у рамках даного партнерства, і перш за все, сорормулювати мету, а потім вже скласти і реалізувати план співпраці у рамках партнерства.

Також дуже важливо визначити потенційні результати сумісної діяльності.

Врахування комплексу зазначених умов для побудови партнерства дозволяє закласти стабільну основу для подальшої стійкої та ефрективної співпраці.

Одним 3 основних завдань, які стоять перед університетськими клініками, організованими на принципах державно-приватного партнерства, $€$ забезпечення достатніх фрінансових ресурсів для виконання програм освітньої, наукової діяльності та надання високоспеціалізованої, якісної та доступної медичної допомоги населенню.

Забезпечення УК необхідними економічними ресурсами є складною проблемою, яка вирішується у рамках економічного регулювання. Складність її посилюється об'єктивними труднощами, з якими на сьогодні стикнулася економіка України.

Рефрормування системи УК на принципах ДПП $€$ передумовою переходу до багатоканального фінансування охорони здоров'я, залучення для цієї мети коштів приватних інвесторів, населення. Багатоканальність отримання фрінансових ресурсів вимагає систематизації та обліку усіх наявних джерел фрінансування діяльності УК.

Оскільки діяльність УК на принципах ДПП в умовах ринку набуде нового фрінансового механізму, то необхідно буде забезпечити більш повну оцінку проблем фрінансового забезпечення УК і більш раціональне використання фрінансових коштів, що залежить насамперед від ефективного управління ними на рівні УК.

Фінансове управління потребуватиме таких змін:

- управління повинно перейти на економічні методи $з$ метою підвищення рентабельності виробництва і продажу медичних послуг;

- необхідно запровадити фрінансовий менеджмент - прийняття управлінських рішень на основі 
аналізу джерел фрінансування, оптимізації використання ресурсів, досягнення ефективності управління УК;

- фрінансовий менеджмент як частина фрінансового механізму, який включає фрінансові методи і важелі, правове, нормативне та інформаційне забезпечення, має стати основою для розробки технології управління фрінансовими ресурсами УК на принципах ДПП;

- фрінансове управління в УК на принципах дПП має розглядатися як сукупність виробничої, забезпечуючої та керуючої підсистеми УК;

- за допомогою елементів фінансового механізму необхідно проводити аналіз діяльності даних підсистем у моделі УК і моделювати взаємодію і взаємозв'язок між ними.

Необхідно також розробити комплекс методичних підходів, застосування яких дозволить побудувати модель взаємодії пацієнта і виробника медичних послуг, визначити основні напрямки оптимізації використання ресурсів у підсистемах УК.

Фінансовий стан УК буде оцінюватися за сукупністю показників, які відображають наявність, розміщення і використання фрінансових ресурсів. Тому необхідно буде використовувати методологію системного аналізу із застосуванням технології фрінансового менеджменту. Результати такої оцінки визначать шляхи подальшого удосконалення управління фрінансовими ресурсами на рівні УК.

Можна виділити основний перелік напрямків інвестування державою і приватним інвестором УК у рамках проектів державно-приватного партнерства:

- створення сучасної матеріально-технічної бази УК;

- розвиток організаційної інфрраструктури УК;

- підвищення доступності, рівня і якості медичних послуг, які надають УК населенню;

- розробка наукових досліджень на базі УК;

- підтримка зв'язку УК із зарубіжними вищими навчальними закладами;

- здійснення програм міжвузівського обміну студентами;

- оптимізація освітніх програм для УК;

- розробка професійних стандартів, кваліфікаційних вимог і посадових обов'язків медичного персоналу та працівників навчальних закладів, які залучені до роботи в УК;

- акредитація програм і незалежна оцінка якості підготовки студентів;

- цільова підготовка кадрів;

- оптимізація науково-виробничої практики та стажування студентів;

- кадрове забезпечення, стажування та перепідготовка викладачів в УК.

Для есрективного управління університетською клінікою на принципах ДПП, раціонального використання фрінансових коштів, організації сучасної матеріально-технічної бази обирають керівника УК.

Керівника УК мають обирати на конкурсній основі. Він повинен мати вчений ступінь доктора медичних наук та диплом магістра за спеціальністю «Управління та адміністрування».

Оскільки одноосібне управління великими державними підприємствами не завжди дозволяє забезпечити повноцінне і прозоре управління, то при УК створюють колегіальний орган управління (Правління), який визначає стратегію розвитку УК, здійснює контроль і моніторинг ходу реалізації проектів, що сприятиме більш якісній розробці прийнятих колегіальних рішень, підвищенню персональної відповідальності.

До складу Правління мають увійти представники приватного інвестора, Міністерства охорони здоров'я України, Міністерства освіти України, місцевого виконавчого органу, університету, населення, керівник університетської клініки і незалежні члени (20 \%). Це дозволить приймати необхідні управлінські рішення і, відповідно, повною мірою ефрективно керувати підприємством.

Також має бути створена підпорядкована Правлінню служба внутрішнього аудиту, діяльність якої забезпечуватиме своєчасне виявлення та усунення фінансово-господарських та медичних ризиків в УК. Цей орган $є$ необхідним для регулярного внутрішнього аудиту фрінансово-господарської діяльності підприємства, оплати праці медичних працівників, цін на медичні послуги, аналізу і контролю діяльності 3 надання медичних послуг із винесенням рекомендацій на розгляд Правління для прийняття коригувальних та запобіжних дій. На службу внутрішнього аудиту повинен бути покладений контроль щодо усунення виявлених порушень.

\section{Висновки}

Державно-приватне партнерство є невід'ємним елементом сучасної економіки країн, які обрали шлях демократичного розвитку, та дозволяє підвищити якісний рівень суспільних благ і сприяє фрормуванню державної політики, адекватної до сучасних умов соціально-економічного розвитку.

ДПП $є$ ефрективним інвестиційним механізмом для впровадження в галузь охорони здоров'я інноваційних практик лікування, навчання кадрів, технологічного оснащення клінік, поліпшення якості надання медичної допомоги та в цілому може сприяти фрормуванню сучасних університетських клінік.

Перспективи подальших досліджень полягають у використанні отриманих результатів для обґрунтування і розробки моделі університетської клініки на принципах ДПП. 


\section{Список літератури}

1. Анализ ГЧП в системе здравоохранения Великобритании // Экспертный журнал. - 2014. - № 4. - С. 36.

2. Гойда Н. Г. Державно-приватне партнерство в діяльності лікарні: світовий досвід та перспективи впровадження в Україні / Н. Г. Гойда, Н.В.Курділь // Східноєвропейський журнал громадського здоров'я. - 2012. - № 2/3. - С. 68-71. 3. Индивидуальные рейтинги УИАМП. Результат исследования [Електронный ресурс]. - Режим доступу к ресурсу : https://uiamp.org.ua/isl/za-5-let-rashody-na-medicinu-v-ukraine-sokratilis-v-2-raza-rezultaty-issledovaniya.

4. Кирченко К. Г. Становление государственно-частного партнерства: общемировой опыт / К. Г. Кирченко // Вестник экономической интеграции. - 2013. - № 5-6. - С. 64-70.

5. Модель университетской клиники uniclinic / А. А. Аканов, К. А. Тулебаев, Б. С. Турдалиева и др. // Вестник КазНМУ. - 2017. - № 2. - С. 68-74.

6. Павлюк К. В. Розвиток державно-приватного партнерства у сфері охорони здоров'я / К. В. Павлюк, Е. В. Степанова // Фінанси України. - 2011. - № 2. - С. 43-55.

7. Сачек М. М. Государственно-частное партнерство в здравоохранении: международный опыт / М. М. Сачек, Н. Е. Хейсрец, В. С. Петров // Вопросы организации и инсрорматизации здравоохранения. - 2016. - № 1. - С. $18-34$. 8. Шевчук Ю. В. Розвиток державно-приватного партнерства у контексті вдосконалення фрінансового забезпечення сорери охорони здоров'я / Ю. В. Шевчук // Економічний вісник університету. - 2017. - Вип. 33 (1). - С. $416-428$.

9. Łakomy-Zinowik M. Public-private partnerships as a way of financing in the healthcare system (Based on the examples of Poland and the United Kingdom) / M. Łakomy-Zinowik // J. Int. Stud. - 2016. - Vol. 9, No. 3. - P. 150-158.

10. Leistungsbericht der Charité - Universitätsmedizin Berlin über das Jahr 2015 zur Umsetzung des Charité-Vertrags 2014 bis $2017 .-40$ p.

\section{References}

1. (2014). Analiz GCHP v sisteme zdravookhraneniya Velikobritanii [Analysis of PPP in the health system of the UK]. Ekspertnyy zhurnal - Expert Journal, 4, 36 [in Russian].

2. Hoida, N.H., \& Kurdil, N.V. (2012). Derzhavno-pryvatne partnerstvo v diialnosti likarni: svitovyi dosvid ta perspektyvy vprovadzhennia v Ukraini [State-private partnership in activity of the hospital: world experience and prospects in Ukraine]. Skhidnoievrop. zhurn. hromad. zdorovia - Eastern European Journal of Public Health, , 2/3, 68-71 [in Ukrainian].

3. Indyvidualnyye reytingi Ukrainskogo instituta analiza i menedzhmenta politiki. Rezultat issledovaniya [Individual ratings of the Ukrainian Institute for Analysis and Policy Management. Research result]. Retrieved from: https://uiamp.org.ua/isl/ za-5-let-rashody-na-medicinu-v-ukraine-sokratilis-v-2-raza-rezultaty-issledovaniya [in Russian].

4. Kirchenko, K.G. (2013). Stanovleniye gosudarstvenno-chastnogo partnerstva: obshchemirovoy opyt [The formation of public-private partnerships: global experience]. Vestnik ekonomicheskoy integratsii - Bulletin of Economic Integration, 5-6, 64-70 [in Russian].

5. Akanov, A.A., Tulebayev, K.A., Turdaliyeva, B.S., \& Kurakbayev, K.K., (2017). Model universitetskoy kliniki uniclinic [Model of a university clinic uniclinic]. Vestnik KazNMU - Bulletin of Kazan NMU, 2, 68-74 [in Russian].

6. Pavliuk, K.V., \& Stepanova, Ye.V. (2011). Rozvytok derzhavno-pryvatnoho partnerstva u sferi okhorony zdorovia [Development of public-private partnership in the field of health care]. Finansy Ukrainy - Finance of Ukraine, 2, 43-55 [in Ukrainian].

7. Sachek, M.M., Kheyfets, N.Ye., \& Petrov, V.S. (2016). Gosudarstvenno-chastnoye partnorstvo v zdravookhranenii: mezhdunarodnyy opyt [Public-private partnership in healthcare: international experience]. Vopr. organizatsii i informatizatsii zdravookhraneniya - Issues of Organization and Informatization of Healthcare, 1, 18-34.

8. Shevchuk, Yu.V. (2017). Rozvytok derzhavno-pryvatnoho partnerstva u konteksti vdoskonalennia finansovoho zabezpechennia sfery okhorony zdorovia [Development of public-private partnership in the context of improving the financial support of the healthcare sector]. Ekonomichnyi visnyk universytetu - Economic Bulletin of the University, 33 (1), 416-428 [in Ukrainian].

9. Łakomy-Zinowik, M. (2016). Public-private partnerships as a way of financing in the healthcare system (Based on the examples of Poland and the United Kingdom). J. Int. Stud. 9 (3), 150-158.

10. Leistungsbericht der Charité - Universitätsmedizin Berlin über das Jahr 2015zur Umsetzung des Charité-Vertrags 2014 bis 2017.

\section{ИНВЕСТИРОВАНИЕ В УНИВЕРСИТЕТСКИЕ КЛИНИКИ НА ОСНОВЕ МЕХАНИЗМА ГОСУДАРСТВЕННО-ЧАСТНОГО ПАРТНЕРСТВА}

\section{В. Д. Чопчик}

Стоматологический медицинский центр Национального медицинского университета имени А. А. Богомольца,

г. Киев, Украина

Цель: рассмотреть возможность инвестирования в университетские клиники на основе использования механизма государственно-частного партнерства (ГЧП).

Материалы и методы. Для достижения поставленной цели в работе применяли общенаучные методы анализа, синтеза, обобщения, интерпретации научных данных, а также системный и структурнофункциональный подходы. Информационной базой исследования являются научные работы отечественных и зарубежных специалистов по ГЧП и менеджменту. 
Результаты. Ограничения фринансовых ресурсов в здравоохранении обусловило проблему инвестирований университетских клиник и необходимость поиска новых, эффеективных форм реализации инвестиционной деятельности.

В статье рассматривается возможность инвестирования в университетские клиники на основе использования механизма государственно-частного партнерства. При переходе университетской клиники на работу на принципах ГЧП меняется статус клиники, она становится юридически и хозяйственно самостоятельным учреждением, в котором управление переходит к частному инвестору, но сама клиника остается в государственной собственности. Инвестирование реализуется на основе договора и программ с определением прав и обязанностей партнеров. Предложен алгоритм реализации проекта государственно-частного партнерства, который обеспечивает инвестирование и фрормирование современных клинических баз университетов, развивает бизнес-процессы, привлекающие ресурсы частного инвестора и повышающие эфрфективность работы университетской клиники.

Выводы. В статье определены векторы инвестирования в университетские клиники через механизмы государственно-частного партнерства, а также основные условия реализации ГЧП в университетских клиниках.

КЛЮЧЕВЫЕ СЛОВА: университетская клиника; государственно-частное партнерство.

\section{INVESTING TO UNIVERSITY CLINICS ON THE BASIS OF PUBLIC-PRIVATE PARTNERSHIP MECHANISM}

V. D. Chopchik

Dental Medical Center of O. Bohomolets National Medical University, Kyiv, Ukraine

Purpose: to consider the possibility of investing in university clinics using the mechanism of public-private partnership (PPP)

Materials and Methods. To achieve this goal, general scientific methods of analysis, synthesis, generalization, interpretation of scientific data, as well as systemic and structural-functional approaches were used.

Results. The limited financial resources in healthcare created a problem with the investment to university clinics and necessitated the search for new, effective forms of implementing investment activities.

The article discusses the possibility of investing in university clinics through the use of public-private partnerships. When a university clinic works on the principles of PPP, the status of the clinic changes, it becomes a legally and economically independent institution in which management passes to a private investor, but the clinic itself remains in state ownership. Investing is carried out on the basis of an agreement and programs with the definition of the rights and obligations of partners. An algorithm is proposed for the implementation of a publicprivate partnership project, which ensures investment and the formation of modern clinical bases of universities, develops business processes that attract the resources of a private investors and increase the efficiency of the university clinic.

Conclusions. The article defines the vectors of investment in university clinics through PPP mechanisms, as well as the main conditions for the implementation of PPP in university clinics.

KEY WORDS: university clinic; public-private partnership.

Рукопис надійшов до редакції 25.07.2019 p.

\section{Відомості про автора:}

Чопчик Віталій Дмитрович - кандидат медичних наук, в. о. заступника директора з медичної частини Стоматологічного медичного центру Національного медичного університету імені О. О. Богомольця;

тел.: + 38(044) 454-49-69; +38(067) 383-34-23. 